\title{
Hepatoprotective and Haematoprotective Roles of Gongronema latifolium Benth Aqueous Extract in Alloxan- Induced Diabetic Rats
}

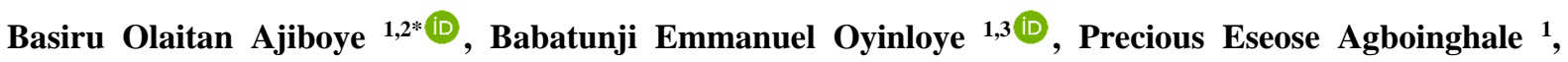 \\ Oluwafemi Adeleke Ojo ${ }^{4, *(\mathbb{D})}$
}

1 Phytomedicine, Biochemical Toxicology and Biotechnology Research Laboratory, Department of Biochemistry, College of Sciences, Afe Babalola University, Ado-Ekiti, Ekiti State, Nigeria

2 Department of Biochemistry, Federal University Oye-Ekiti, Oye-Ekiti, Nigeria

3 Biotechnology and Structural Biology (BSB) Group, Department of Biochemistry and Microbiology, University of Zululand, KwaDlangezwa 3886, South Africa

4 Department of Biochemistry, Landmark University, Omu-Aran, Kwara State, Nigeria

* Correspondence: bash1428@yahoo.co.uk (B.O.A.); oluwafemiadeleke08@gmail.com (O.A.O.);

Scopus Author ID: 56415952100

Received: 2.03.2021; Revised: 4.04.2021; Accepted: 8.04.2021; Published: 20.04.2021

\begin{abstract}
This research evaluates the hepatoprotective and haematoprotective abilities of the extract of Gongronema latifolium leaves in diabetic rats. Forty animals were induced intraperitoneal using alloxan of $150 \mathrm{mg} / \mathrm{kg}$ body weight. The Wistar rats were thereafter divided as follows: normal control, diabetic untreated control, diabetic rats received $5 \mathrm{mg} / \mathrm{kg}$ body weight of metformin, and diabetic rats received three ethnobotanical doses $(6.36,12.72$, and $25.44 \mathrm{mg} / \mathrm{kg}$ body weight) of aqueous extract of $G$. latifolium leaves (AEGLL). On the 14th day of the experiment, the rats were relinquished, and various hepatoprotective and haematoprotective biomarkers were assessed. Diabetic rats administered AGELL demonstrated normoglycaemia, reduced inflammatory levels as well as activities of transaminases. Also, diabetic animals that received AGELL show a substantial increase in protein, albumin, and hematological parameters determined when linked to diabetic control rats. Hence, three ethnobotanical doses revealed the hepatoprotective and haematoprotective nature of this plant.
\end{abstract}

Keywords: ethnobotanical; diabetic; G. latifolium; liver; hematological; hepatoprotective.

(C) 2021 by the authors. This article is an open-access article distributed under the terms and conditions of the Creative Commons Attribution (CC BY) license (https://creativecommons.org/licenses/by/4.0/).

\section{Introduction}

Ludidi et al. [1] documented that reactive oxygen species (ROS) are associated with the production of different diseases like atherosclerosis, diabetes mellitus, cancer, amongst others. In diabetes mellitus (DM) condition, there is a derangement of pancreatic islets function leading to the accumulation of circulating blood glucose levels linked to a rise in reactive oxygen species, as reported by Sonkamble et al. [2]. This abnormal increase in ROS over endogenous antioxidant defense mechanism triggers an increase in oxidative stress, leading to defects in insulin secretion [2]. This encourages different diabetes mellitus complications, most especially hepatopathy. The liver is an important organ in the body system that plays crucial functions in the metabolism of nutrients, such as in carbohydrate metabolism and generation of glucose from non-carbohydrate precursors in a process called gluconeogenesis. The liver is more prone to diabetes mellitus that accounts for more than $75 \%$ of death cases [3]. Several 
biomarkers prove hepatopathy or liver damage in diabetes mellitus conditions; these include anti-inflammatory, serum transaminase enzyme activities, etc. [4].

In another vein, anemia is another problem associated with severe diabetes mellitus condition because of insufficient and effective red blood cells (RBC) and hemoglobin (i.e., an oxygen-binding component of the blood). This is so because of persistent hyperglycemia in diabetic conditions [5].

Several drugs are presently available for the treatment of DM and all associated complications globally. Hence, they have features of negative side effects. However, herbal medicine has been described as the most accessible and affordable [6]. Notably, several medicinal plants have been reported, but Gongronema latifolium leaves have been reported locally to manage this disorder and its complications. This plant is commonly found in every part of Nigeria, especially the Southern region of this country. Little research has been done on its leaf, as reported by [7-9]. Because of the lack of scientific evidence on the plant's hepatoprotective properties, this study was designed to investigate the hepatoprotective and haemoprotective effects of aqueous extract of $G$. latifolium leaves in alloxan-induced diabetic rats.

\section{Materials and Methods}

\subsection{Plant materials and authentication.}

Gongronema latifolium leaves were bought from Ekpoma Market, Edo State, Nigeria. This was recognized at the Forestry Research Institute of Nigeria (FRIN), Ibadan, Nigeria. It was then allocated a specimen number FHI 112032.

\subsection{Processing of G.latifolium leaves (GLL).}

G. latifolium leaves were air-dried for four weeks and pulverized into fine particles through an electric blender. Then its specific grams (200 grams) were water-logged in (2000 $\mathrm{mL}$ ) distilled water for 24 hours with intermittent stirring at room temperature, sieved, and freeze-dried to attain dried extract, which was weighed and kept exclusively in the fridge. Notably, based on the ethnobotanical survey, $250 \mathrm{~mL}$ (equivalent to a cup) of the filtrate was freeze-dried individually to achieve a yield equivalent to what was consumed by a $70 \mathrm{~kg}$ man, and subsequently, deduced to acquire $12.72 \mathrm{mg} / \mathrm{kg}$ body weight (70 $\mathrm{kg}$ man dose). Hence, this was multiplied and divided by a factor of 2 to obtain both high $(25.44 \mathrm{mg} / \mathrm{kg})$ and low $(6.39$ $\mathrm{mg} / \mathrm{kg}$ ) ethnobotanical doses as initially documented by [10].

\subsection{Animals study.}

Forty-eight female (single-sex were used to avoid mating) Wistar rats of five to seven weeks old (120-135 g), obtained in Animal Holding Section, Afe Babalola University, AdoEkiti. These animals were agreed to consume freely standard laboratory food, water and conserved beneath standard conditions of temperature at $25^{\circ} \mathrm{C}$. This experiment was approved by the Animal Ethical Committee of Afe Babalola University with number ABUAD/SCI/03/004. 


\subsection{Induction of diabetes mellitus into the experimental animals.}

This was done via a sole intraperitoneal dose $(150 \mathrm{mg} / \mathrm{kg}$ body weight $)$ of newly prepared alloxan in $0.9 \%$ normal saline solution. Hence, forty-eight hours after the alloxan injection, blood was acquired from the rat tails' tips for estimating their fasting blood glucose (FBG) levels via Accu-Chek Active glucometer (Roche Diagnostics, Manheim, Germany) to know those that had diabetes. Animals that had FBG levels of $\geq 250 \mathrm{mg} / \mathrm{dl}$ were considered diabetes and employed in this study [11].

\subsection{Animal grouping.}

Thereafter, the animals were grouped randomly into 6 groups of 8 animals.

Group 1: Normal control rats received $1 \mathrm{ml}$ of distilled water

Group 2: Diabetic untreated rats

Group 3: Diabetic rats received $5 \mathrm{mg} / \mathrm{kg}$ body weight of metformin

Group 4: Diabetic rats received $6.36 \mathrm{mg} / \mathrm{kg}$ body weight of aqueous extract GLL

Group 5: Diabetic rats received $12.72 \mathrm{mg} / \mathrm{kg}$ body weight of aqueous extract GLL

Group 6: Diabetic rats received $25.44 \mathrm{mg} / \mathrm{kg}$ body weight of aqueous extract GLL

Note that the oral administration route was used for both the extract and metformin every day for thirteen days.

\subsection{Collection and treatment of samples.}

The sacrificing of the animals took place on the fourteenth days using cervical dislocation. Blood of each animal was collected into an EDTA tube and a plain tube via cardiac puncturing, left at room temperature for $1 / 2$ of an hour, and centrifuged at $3000 \mathrm{rpm}$ for 600 seconds to acquire a supernatant using a Pasteur pipette. The liver was also quickly eliminated, washed with normal saline, homogenized, and centrifuged at $4000 \mathrm{rpm}$ for 900 seconds [10].

\subsection{Biochemical parameters determined.}

2.7.1. Fasting blood glucose level estimation.

This was estimated in each animal in their respective group using the glucometer (Roche Diagnostics, Manheim, Germany) [12].

\subsubsection{Inflammatory markers determination.}

The levels of interleukin IL-6, interleukin IL-2, and tumor necrosis factor (TNF)- $\boldsymbol{\alpha}$ were measured in the serum from all the rats using ELISA kits (Biosource, USA) at $450 \mathrm{~nm}$.

\subsubsection{Determination of liver function indices.}

The aspartate transaminase (AST), alanine transaminase (ALT), gamma-glutamyl transferase (GGT), alkaline phosphatase (ALP), total protein, and albumin were determined using Automated Chemistry Analyzer (Randox; County Antrim, UK) by following guidelines outlined by the manufacture. 
2.7.4. Determination of hematological parameters.

The packed cell volume (PCV), hemoglobin ( $\mathrm{Hb})$, red blood cell ( $\mathrm{RBC})$, mean corpuscular hemoglobin concentration (MCHC), mean cell volume (MCV), mean corpuscular hemoglobin $(\mathrm{MCH})$, and white blood cell (WBC) using Automated Haematology AnalyzerMC-2800 (Mindray Company, China) following the method described by the manufacturer.

\subsection{Data analysis.}

The obtained results were reported as the mean of eight replicates \pm standard deviation (SD). This was archived via Graph pad prism 5 software. One-way ANOVA was used followed by a post hoc, and a significant difference was acquired at $\mathrm{p}<0.05$.

\section{Results and Discussion}

\subsection{Changes in the fasting blood glucose (FBG) levels in diabetic rats administered $G$.} latifolium.

There was no significant difference in the FBG of all the groups before induction. However, all animal groups except the normal control rats demonstrated a noteworthy rise in FBG level at $48 \mathrm{~h}$ of induction. On the 14th day of treatment, the groups administered the doses of extract of G. latifolium leaf shows a momentous reduction in the FBG levels when compared with diabetic untreated rats (Figure 1). There are different therapeutic plants employed for the treatment/management of human disorders globally. Liver diseases have become a health burden worldwide, especially in diabetes mellitus patients. This may be acclaimed to toxic agents' exposures to induce endogenous oxidative stress and tissue impairment [13]. In this study, alloxan was employed to induce diabetes mellitus via stimulating selective pancreatic $\beta$ cells destruction, as reported by Szkudelski [14]. This damage trigger hyperglycemia (Figure 1). However, the administration of ethnobotanical doses of G. latifolium extract reversed hyperglycemia, probably by inhibiting glucose absorption in the intestine that facilitates glucose movement from the liver $[10,15]$.

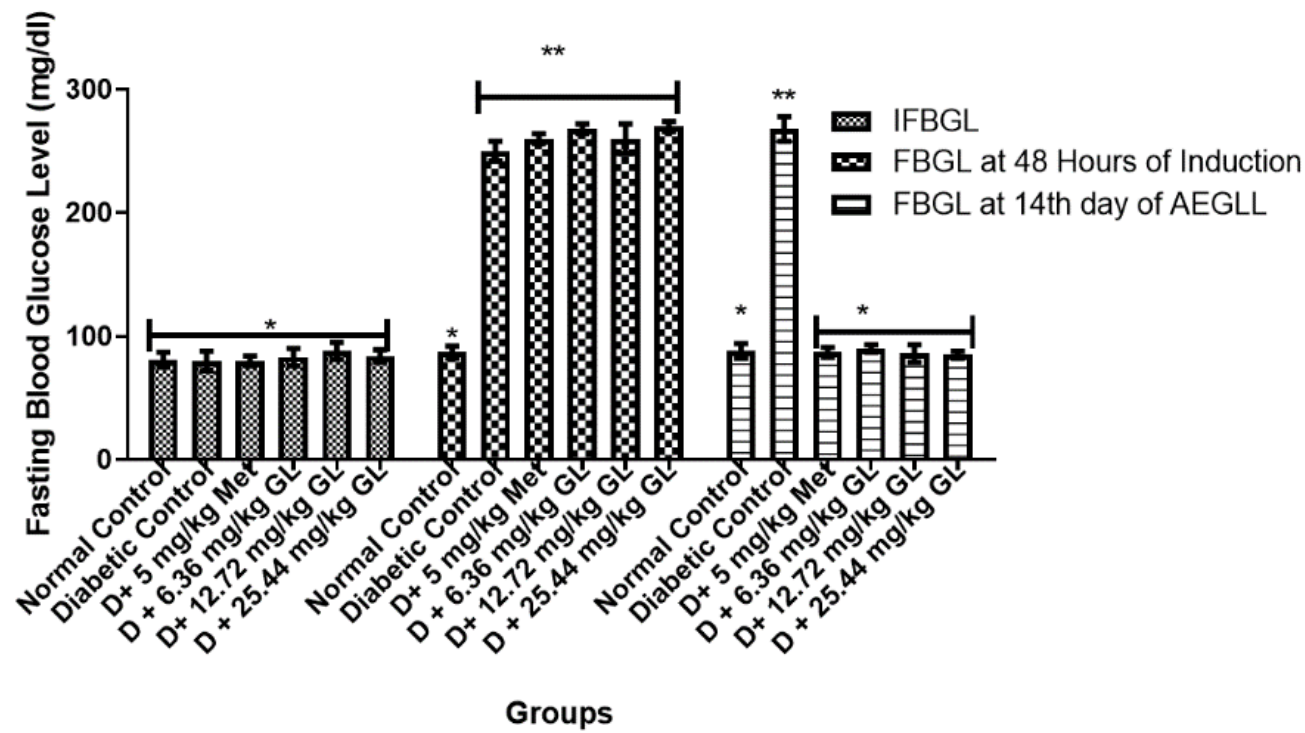

Figure 1. G. latifolium leaf on fasting blood glucose level of diabetic rats.

- $\quad(\mathrm{n}=8 \pm$ standard deviation (SD))

- Legend: $*$ and $* *$ are significantly different at $\mathrm{p}<0.05, *$ and $*$ are not significantly different at $\mathrm{p}>0.05$

- GL-Gongronema latifolium, Met-metformin, Diab-diabetic, IFBGL-intimal fasting blood glucose level, FBGL-fasting blood glucose level, AEGLL aqueous leaf extract Gongronema latifolium leaf. 


\subsection{Changes in the levels of some inflammatory markers administered G. latifolium leaf.}

As illustrated in Figure 2, the result shows that the levels of IL-6, IL-2, and TNF- $\alpha$ in the liver of the diabetic control animals were significantly $(\mathrm{p}<0.05)$ increased compared to other groups. Conversely, there was no considerable decrease in the levels of IL-6 in diabetic animals that received $6.36,12.72$, and $25.44 \mathrm{mg} / \mathrm{kg}$ body weight of aqueous extract $G$. latifolium leaf when compared with normal control rats. IL-2 demonstrated no noteworthy differences in diabetic rats that received $5 \mathrm{mg} / \mathrm{kg}$ of metformin and extract of G. latifolium leaf when compared to normal control animals. Also, TNF- $\alpha$ demonstrated no noticeable difference in diabetic rats that received 12.72 and $25.44 \mathrm{mg} / \mathrm{kg}$ aqueous extract $G$. latifolium leaf compared with normal control. Diabetic animals administered $5 \mathrm{mg} / \mathrm{kg}$ metformin and 6.36 $\mathrm{mg} / \mathrm{kg} \mathrm{G}$. latifolium extract exhibited no statistical difference in TNF- $\alpha$ level. The increase in the pro-inflammatory cytokines detected in diabetic rats due to toxicant exposure (Figure 2) may result from macrophage stimulation by high glucose. These pro-inflammatory cytokines are produced chiefly by activated macrophages such as the natural killer cells, lymphocytes, neutrophils, etc. [16]. The extract of G. latifolium leaves was capable of reducing the proinflammatory cytokine level, as witnessed in this experiment, probably due to the extract's capacity to normalize the production of activated macrophages produced during inflammation. This justifies that the extract of $G$. latifolium leaves possesses anti-inflammatory potential. The is in covenant with the preceding report by Ogunyinka et al. [16].
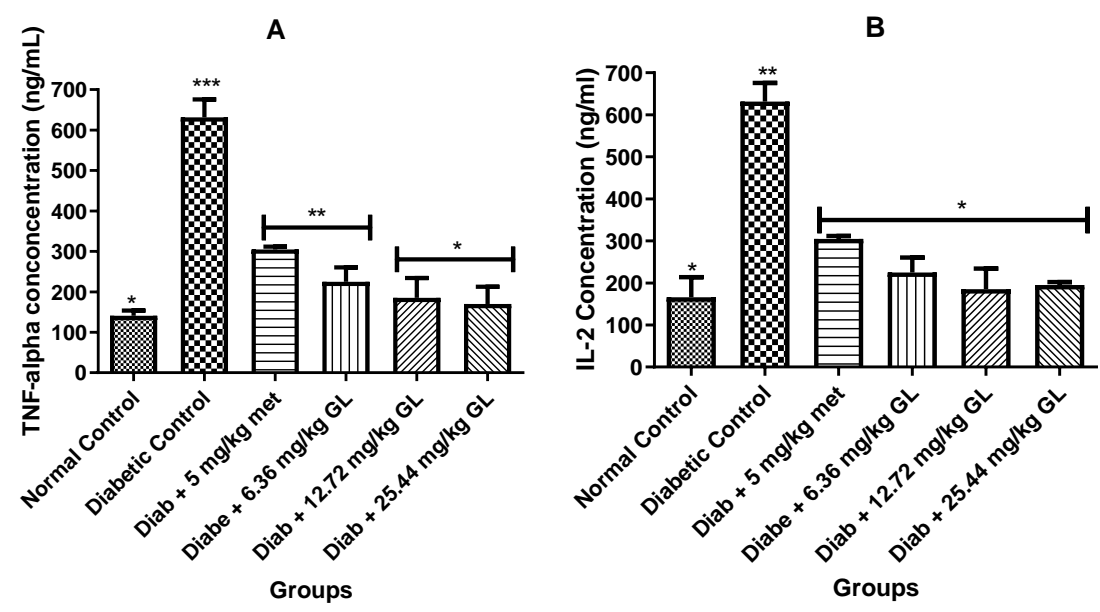

C

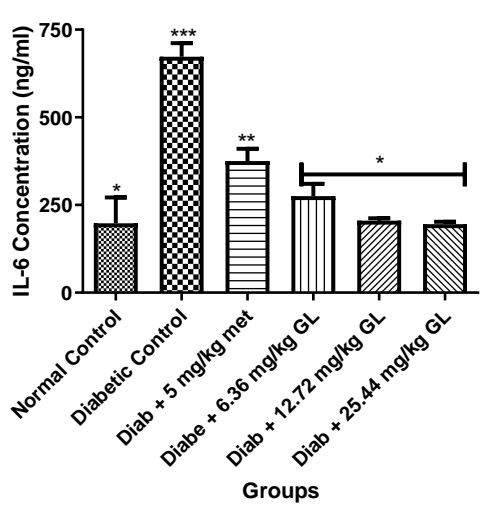

Figure 2. G. latifolium leaf on some inflammatory concentration in the liver of diabetic rats.

- $\quad(\mathrm{n}=8 \pm$ standard deviation (SD)

- Legend: * and $* *$ are significantly different at $\mathrm{p}<0.05$, *and * are not significantly different at $\mathrm{p}>0.05$, and $* *$ and $* * *$ are significantly different at $\mathrm{p}<0.05$

- GL-Gongronema latifolium, Met-metformin, Diab-diabetic, IL-2-interleukin2, IL-6-interleukin6, TnF-tumor necrosis factor. 


\subsection{Changes in the serum liver function indices in diabetic rats administered G. latifolium} leaf

There was an increment in AST, ALT, GGT, and ALP activities in the serum of diabetic control animals linked to other groups. Hence, there was no significant difference in AST, ALT, and GGT activities in the groups that received metformin and extract of G. latifolium in comparison to normal control rats. In ALP, diabetic rats received 12.72 and $25.44 \mathrm{mg} / \mathrm{kg}$ body weight of aqueous extract $G$. latifolium leaf shows no considerable difference when compared to normal control rats (Figure 3). Giving by Oyebode et al. [17], the main markers of liver injury are transferases (ALT, AST, and GGT) (Figure 3). These are mainly prominent in the liver, and they are critically involved in the metabolism of amino acids. Alloxan-toxicity has been linked with alterations in the liver membrane's penetrability, which encourages cellular seepage of these enzymes (ALT, AST, and GGT) from the liver cells into the blood-stream [16]. Whereas alkaline phosphatase (ALP), an indicator of cholestasis, was reported by Malakouti et al. [18]. In the current study, all these enzyme activities were markedly enhanced in diabetic control animals, suggesting some degree of liver damage, an indicator of hepatopathy (Figure 3). This is in pact with the prior statement by Ogunyinka et al. [16], amongst others. However, the diabetic animals received ethnobotanical doses of G. latifolium extract show its capability to normalize the abnormal increase in these enzyme activities and revealed the extract's hepatoprotective effect.

A

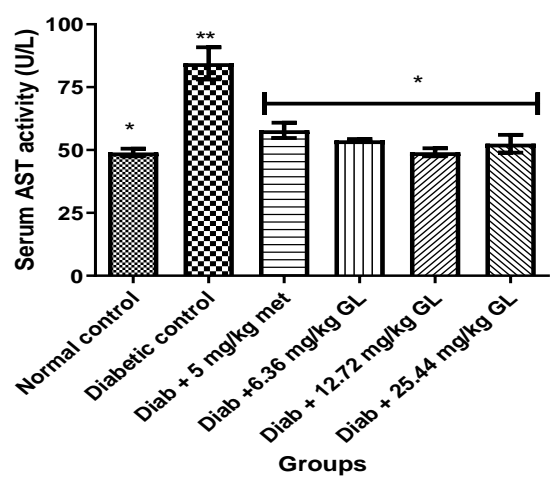

C

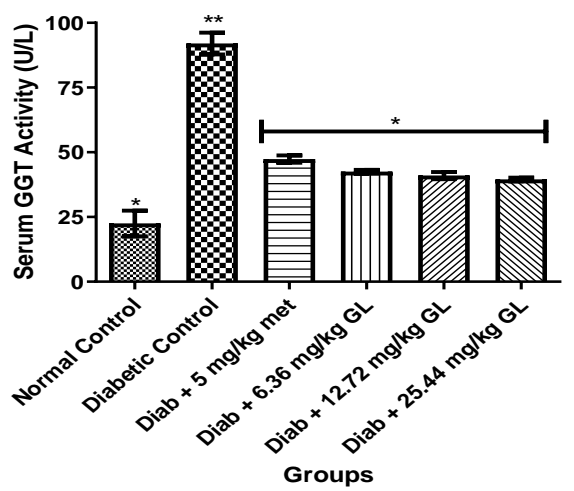

B

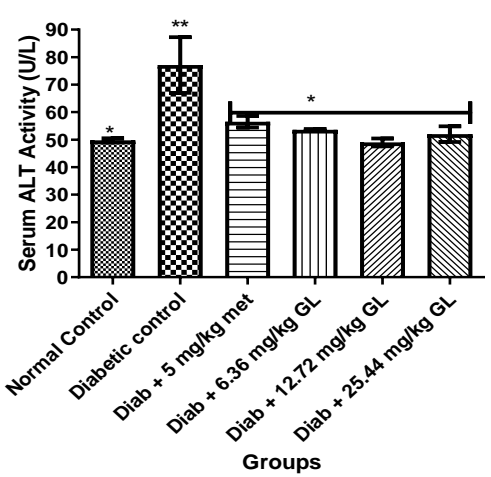

D

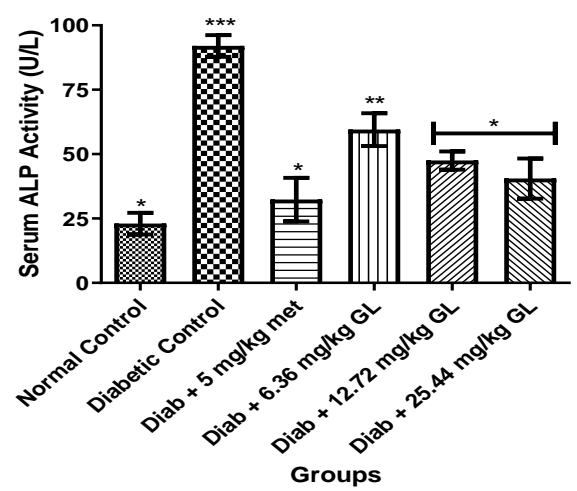

Figure 3. G. latifolium leaf on some liver function enzymes in diabetic rats.

- $\quad(\mathrm{n}=8 \pm$ standard deviation (SD))

- Legend: * and ** are significantly different at $\mathrm{p}<0.05$, *and * are not significantly different at $\mathrm{p}>0.05$, and $* *$ and $* * *$ are not significantly different at $\mathrm{p}<0.05$, GL-Gongronema latifolium, Met-metformin, Diab-diabetic, AST-aspartate transferase, ALT- alanine transferase, GGT- glutamyl transferase, ALP-alkaline phosphatase.

Besides, there was a significant decline in protein and albumin levels in diabetic untreated rats. Hence, at the experiment's termination period, there was no significant 
difference in the groups that received 6.36, 12.72, and $25.44 \mathrm{mg} / \mathrm{kg}$ extract G. latifolium leaf compared to albumin levels. Furthermore, proteins are the main part of all dissolved constituents in the bloodstream, and they are the main components of enzymes in the human body system [19]. The insufficient insulin action in diabetes mellitus leads to an imbalance in amino acid/protein metabolism, leading to an increase in gluconeogenesis [16]. This may be probably responsible for the reduction in protein levels in diabetic control animals. But the diabetic rats received ethnobotanical doses of $G$. latifolium extract displays normal protein metabolism, as indicated in Figure 4. Also, albumin is synthesized in the liver, and it serves in the circulation of extracellular fluids, control of osmotic pressure, transport agents for hormones, vitamins, etc. Kasole et al. [20] reported that a decreased level of albumin is noticed in diabetes mellitus due to liver disease. This was supported in the diabetic control group of the current study with an abnormal decrease in albumin level, revealing hepatopathy (Figure 4). Treatment of diabetic rats with ethnobotanical doses of G. latifolium extract reversed this back to normal, which may be attributed to the extract anti-hepatopathy potentials.
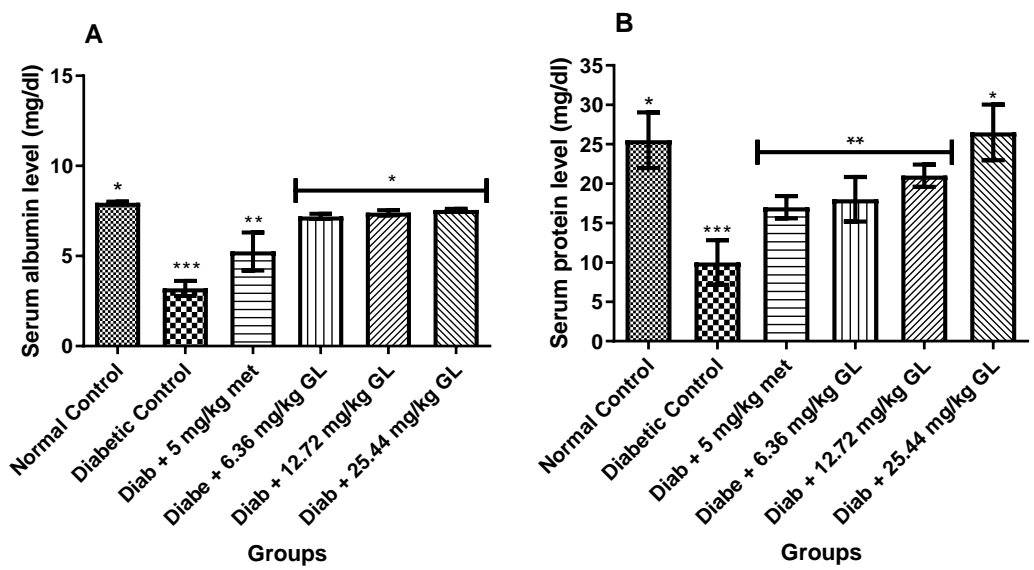

Figure 4. G. latifolium leaf on serum albumin and protein in diabetic rats.

- $\quad(\mathrm{n}=8 \pm$ standard deviation $(\mathrm{SD}))$

- Legend: * and $* *$ are significantly different at $\mathrm{p}<0.05$, *and $*$ are not significantly different at $\mathrm{p}>0.05$, and $* *$ and $* * *$ are significantly different at $\mathrm{p}<0.05$ - GL-Gongronema latifolium, Met-metformin, Diab-diabetic.

\subsection{Changes in the levels of some hematological parameters in diabetic rats}

There was a substantial decrease in PCV, Hb, RBC, MCHC, MCV, MCH, and WBC in diabetic control animals linked to other groups. Nevertheless, groups that received 6.36, 12.72 , and $25.44 \mathrm{mg} / \mathrm{kg}$ extract of $G$. latifolium leaf demonstrated a significant increase in all the hematological parameters studied. Also, diabetic rats received 12.72 and $25.44 \mathrm{mg} / \mathrm{kg}$ extract of G. latifolium leaf show no significant ( $>>0.05$ ) difference in $\mathrm{MCH}, \mathrm{MCV}, \mathrm{Hb}$, and MCHC when linked to normal control (Table 1). But in WBC, PCV, and RBC, only diabetic rats administered with the highest dose of $G$. latifolium leaf extract show no noticeable difference when linked to normal rats. Hematological parameters evaluation has been reported to be a useful tool in revealing the harmful effect of plant extracts on animal's blood composition and determining possible alterations in enzyme activities due to tissue damage (e.g., liver) as documented by [21]. The existence of anemia as one of the complications in diabetes mellitus might be linked to an upsurge in non-enzymatic glycosylation [22]. This encourages an enhancement in the generation of lipid peroxides, resulting in a decrease in $\mathrm{RBC}$, $\mathrm{Hb}, \mathrm{PCV}, \mathrm{MCH}, \mathrm{MCV}$, and MCHC in diabetic control animals (Table 1), an indicator of anemia. Hence, the diabetic rats established on ethnobotanical doses of G. latifolium extract reversed these abnormalities and probably prevented anemia (haematoprotective). This is in 
agreement with an earlier statement by [21]. In another vein, the decrease observed in WBC of diabetic control rats may be linked to an increase in inflammation. Therefore, the diabetic rats received ethnobotanical doses of $G$. latifolium extract, which backing its anti-inflammatory potentials. It is noteworthy that this extract's hepatoprotective and haematoprotective abilities may be attributed to flavonoids, alkaloids, terpenoids, anthraquinones, and polyphenols, $\beta$ sitosterol, phytosterols, terpenes, anthocyanidins, etc., as reported by Balogun et al. [23].

Table 1. Aqueous extract of G. latifolium leaf on some hematological parameters in alloxan-diabetic rats.

\begin{tabular}{|c|c|c|c|c|c|c|c|}
\hline Grouping & $\operatorname{PCV}(\mathrm{L} / \mathrm{L})$ & $\mathrm{Hb}(\mathrm{g} / \mathrm{L})$ & $\begin{array}{c}\text { RBC } \\
\left(\mathbf{X ~ 1 0}^{12} / \mathrm{L}\right)\end{array}$ & $\operatorname{MCHC}(\mathrm{g} / \mathrm{L})$ & MCV (fL) & MCH (pg) & $\begin{array}{c}\text { WBC } \\
\left(\mathbf{X 1 0}^{9} / \mathbf{L}\right)\end{array}$ \\
\hline $\begin{array}{l}\text { Normal } \\
\text { Control }\end{array}$ & $6.10 \pm 1.2^{\mathrm{a}}$ & $160.01 \pm 19.56^{\mathrm{a}}$ & $5.12 \pm 2.11^{\mathrm{a}}$ & $334.39 \pm 11.56^{\mathrm{a}}$ & $100.23 \pm 10.34^{\mathrm{a}}$ & $45.12 \pm 10.23^{\mathrm{a}}$ & $15.78 \pm 7.67^{\mathrm{a}}$ \\
\hline $\begin{array}{l}\text { Diabetic } \\
\text { Control }\end{array}$ & $1.40 \pm 0.1^{\mathrm{d}}$ & $60.23 \pm 10.07^{\mathrm{d}}$ & $1.84 \pm 0.12^{\mathrm{d}}$ & $100.67 \pm 10.45^{\mathrm{d}}$ & $48.10 \pm 9.12^{\mathrm{d}}$ & $18.23 \pm 12.45^{\mathrm{c}}$ & $5.67 \pm 2.13^{d}$ \\
\hline $\begin{array}{c}\text { Diab + 5 } \\
\mathrm{mg} / \mathrm{kg} \\
\text { Met }\end{array}$ & $3.23 \pm 0.89^{\mathrm{c}}$ & $145.93 \pm 16.34^{\mathrm{c}}$ & $3.34 \pm 1.67^{\mathrm{c}}$ & $250.34 \pm 13.89^{c}$ & $82.08 \pm 12.07^{\mathrm{c}}$ & $33.12 \pm 17.13^{\mathrm{b}}$ & $10.34 \pm 4.90^{c}$ \\
\hline $\begin{array}{c}\text { Diab + } \\
6.36 \\
\mathrm{mg} / \mathrm{kg} \mathrm{GL}\end{array}$ & $4.21 \pm 2.02^{\mathrm{b}}$ & $150.20 \pm 18.37^{b}$ & $4.01 \pm 2.10^{\mathrm{b}}$ & $289.38 \pm 15.43^{b}$ & $98.28 \pm 18.23^{b}$ & $35.71 \pm 10.32^{b}$ & $10.98 \pm 5.79^{c}$ \\
\hline $\begin{array}{c}\text { Diab + } \\
12.72 \\
\mathrm{mg} / \mathrm{kg} \mathrm{GL}\end{array}$ & $4.49 \pm 2.84^{\mathrm{b}}$ & $152.23 \pm 15.89^{a}$ & $4.34 \pm 1.23^{\mathrm{b}}$ & $300.90 \pm 14.90^{\mathrm{a}}$ & $100.34 \pm 12.08^{\mathrm{a}}$ & $39.56 \pm 11.87^{\mathrm{a}}$ & $12.87 \pm 8.73^{b}$ \\
\hline $\begin{array}{c}\text { Diab + } \\
25.44 \\
\mathrm{mg} / \mathrm{kg} \mathrm{GL}\end{array}$ & $5.98 \pm 2.47^{\mathrm{a}}$ & $155.98 \pm 20.37^{\mathrm{a}}$ & $4.96 \pm 2.19^{\mathrm{a}}$ & $310.32 \pm 20.10^{\mathrm{a}}$ & $104.07 \pm 15.11^{\mathrm{a}}$ & $40.30 \pm 13.78^{a}$ & $16.98 \pm 9.20^{a}$ \\
\hline
\end{tabular}

\section{Conclusions}

Data obtained showed that the ethnobotanical doses of G. latifolium extract possess hepatoprotective ability via a reduction in anti-inflammatory levels, normalizing AST, ALT, GGT, and ALP activities, increasing protein and albumin levels, and anti-anemic. This supports the local usage of this plant as hepatoprotective.

\section{Funding}

This research received no external funding.

\section{Acknowledgments}

This research has no acknowledgment.

\section{Conflict of Interest}

There is no conflict of interest expressed by the authors.

\section{References}

1. Ludidi, A.; Baloyi, M.C.; Khathi, A.; Sibiya, N.H.; Ngubane, P.S. The effects of Momordica balsamina methanolic extract on haematological function in streptozotocin-induced diabetic rats: effects on selected markers. Biomed. Pharmacother 2019; 116, 108925, https://doi.org/10.1016/j.biopha.2019.108925. 
2. Sonkamble, V.V.; Wagh, N.S.; Pai, S.R. Role of Plant Secondary Metabolites as Antidiabetic Agents. In Natural Bio-active Compounds; Akhtar, M.S.; Swamy, M.K.; Sinniah, U.R. Springer: Singapore, 2019; Volume 1: Production and Applications, 529-550.

3. Ojo, O.A.; Osukoya, O.A.; Ekakitie, L.; Ajiboye, B.O.; Oyinloye, B.E.; Agboinghale, P.E.; Kappo, P.A. Gongronema latifolium leaf extract modulates hyperglycaemia, inhibits redox imbalance and inflammation in alloxan-induced diabetic nephropathy. Journal of Diabetes and Metabolic disorders 2020, 19, 469-481, https://doi.org/10.1007/s40200-020-00533-0.

4. Udoudoh, P.M.; Uti, D.E.; Edet, E.E.; Etukudoh, S.N.; Ukwak, B.G.; Obeten, U.N.; Umoru, G.U. Synergistic Anti-diabetic Activity of Gongronema latifolium and Telfairia occidentalis Leaves Extracts on Hepatic Function and Hematological Indices in Wistar Rats. Asian J Biol Sci 2020, 13, 42-52, https://doi.org/10.3923/ajbs.2020.42.52.

5. Idoko, A.; Emmanuel, U.G. Study on fresh leaf aqueous extract of flacourtia indica for hepatoprotective, anti-anemic and hypoglycemic abilities in ccl4 induced hepatotoxicity in albino wistar rats. Universal Journal of Pharmaceutical Research 2019; 4, 17-23, https://doi.org/10.22270/ujpr.v4i1.234

6. Ekakitie, L.; Ajiboye, B.O.; Oyinloye, B.E.; Owero-ozeze, O.S.; Onikanni, S.A.; Ojo, O.A. Attenuation of diabetic nephropathy in alloxan-induced diabetic rats by Solanum macrocapon linn leaves aqueous extract. Comparative Clinical Pathology 2021, 30(2), 173-179, https://doi.org/10.1007/s00580-021-03220-5.

7. Aloke, C.; Ogbodo, P.N.; and Ejike, C.E.C. Hepatoprotective Effects of Ethanol Extracts of Gongronema latifolium Leaves in a Carbon Tetrachloride $\left(\mathrm{CCl}_{4}\right)$-Induced Murine Model of Hepatocellular Injury. Pharmacologia 2018, 9, 55-61.

8. Okesola M.A,; Ojo OA.; Onikanni S.A.; Ajiboye B.O.; Oyinloye B.E.; Agboinghale B.E.; Kappo P.A. Ameliorative Effect of Gongronema latifolium Leaf Extract on Alloxan-induced Diabetic Cardiomyopathy in Wistar Rats Model. Comparative Clinical pathology 2020, 29, 865-872, https://doi.org/10.1007/s00580020-03134-8.

9. Ojo O.A.; Okesola M.A.; Ekakitie L.; Ajiboye B.O.; Oyinloye B.E.; Agboinghale P.E.; Onikanni S.A. Gongronema latifolium Benth. leaf extract attenuates diabetes induced neuropathy via inhibition of cognitive, oxidative stress and inflammatory responses. Journal of the Science of Food and Agriculture 2020; 100, 4504-4511, https://doi.org/10.1002/jsfa.10491.

10. Ajiboye, B.O.; Oyinloye, B.E.; Agboinghale, P.E.; Onikanni, S.A.; Asogwa, E.; Kappo, A.P. Antihyperglycaemia and related gene expressions of aqueous extract of Gongronema latifolium leaf in alloxan-induced diabetic rats. Pharmaceutical Biology 2019, 57, 604-611, https://doi.org/10.1080/13880209.2019.1657907.

11. Ajiboye B.O.; Oyinloye B.E; Essien P.E.; Onikanni S.A.; Ojo O.A.; Kappo A.P. Ameliorative potential of Sterculia tragacantha aqueous extract on renal gene expression and biochemical parameters in streptozotocin-induced diabetic rats. Journal of Pharmaceutical Investigation 2021, 51, 103-113, https://doi.org/10.1007/s40005-020-00506-8.

12. Ahmad, M.S.; Pischetsrieder, M.; Ahmed, N. Aged garlic extract and S-allyl cysteine prevent formation of advanced glycation endproducts. Eur J.; Pharmacol. 2007, 561, https://doi.org/10.1016/j.ejphar.2007.01.041.

13. Rashid, U.; Khan, M.R.; Sajid, M.; Antioxidant, anti-inflammatory and hypoglycemic effects of Fagonia olivieri DC on STZ-nicotinamide induced diabetic rats - in vivo and in vitro study. J. Ethnopharmacol 2019, 242, 112038, https://doi.org/10.1016/j.jep.2019.112038.

14. Szkudelski T. The mechanism of alloxan and streptozotocin action in beta cells of the rat pancreas. Physiol Res. 2001, 50, 537-546.

15. Ajiboye B.O.; Oyinloye B.E.; Owero-ozeze O.S.; Okesola M.A.; Ekakitie I.L.; Ojo O.A.; Kappo A.P. Aqueous extract of Solanum macrocarpon Linn leaves abates hyperglycaemia and expression of glucose transporters gene in alloxan-induced diabetic rats. Journal of Endocrinological Investigation 2021, 44, 256276, https://doi.org/10.1007/s40618-020-01280-y.

16. Ogunyinka, B.I.; Oyinloye, B.E.; Osunsanmi, F.O.; Opoku, A.R.; Kappo, A.P.; Protective Effects of Parkia biglobosa Protein Isolate on Streptozotocin-Induced Hepatic Damage and Oxidative Stress in Diabetic Male Rats. Molecules 2017, 22, 1654, https://doi.org/10.3390/molecules22101654.

17. Oyebode, O.A.; Erukainure, O.L.; Sanni, O.; Islam, M.S.; Crassocephalum rubens (Juss. Ex Jacq.) S. Moore improves pancreatic histology, insulin secretion, liver and kidney functions and ameliorates oxidative stress in fructose-streptozotocin induced type 2 diabetic rats. Drug and Chemical Toxicology 2020, https://doi.org/10.1080/01480545.2020.1716783. 
18. Malakouti, M.; Kataria, A.; Ali, S.K.; Schenker, S.; Elevated liver enzymes in asymptomatic patients what should I do?. J Clin Transl Hepatol. 2017, 5, 394-403, https://doi.org/10.14218/JCTH.2017.00027.

19. Fagbohun, O.F.; Awoniran, P.O.; Babalola, O.O.; Agboola, F.K.; Msagati, T.A.M. Changes in the biochemical, hematological and histopathological parameters in STZ-Induced diabetic rats and the ameliorative effect of Kigelia africana fruit extract. Heliyon 2020, 6, e03989, https://doi.org/10.1016/j.heliyon.2020.e03989.

20. Kasole, R.; Martin, H.D.; Kimiywe, J.; Traditional medicine and its role in the management of diabetes mellitus: "Patients' and herbalists' perspectives. Evidence-Based Complement. Altern. Med 2019. 2019, https://doi.org/10.1155/2019/2835691.

21. Ojo, O.A.; Ojo, A.B.; Ajiboye, B.O.; Imiere, O.; Oyinloye, B.E.; Antihyperlipidemic activities and hematological potentials of ethanol extract of Blighia sapida Koenig bark in alloxan-induced diabetic rats. Serbian Journal of Experimental and Clinical Research 2020, 21, 11-17, https://doi.org/10.2478/sjecr-20180042 .

22. Afolabi, O.B.; Obajuluwa, A.; Obajuluwa, T.; Okiki, P.; Oloyede, O.I.; Fadaka, O.A.; Ojo, O.A.; Exposure to a $2.5 \mathrm{GHz}$ non-ionizing electromagnetic field alters hematological profiles, biochemical parameters and induces oxidative stress in male Albino rats. Biomedical and Environmental Sciences 2019, 32, 860-863. https://doi.org/10.3967/bes2019.107.

23. Balogun, M. E.; Besong, E. E.; Obimma. J. N.; Mbamalu, O. S.; and Djobissie, S. F. A. Gongronema Latifolium: A Phytochemical, Nutritional and Pharmacological Review. J. Phys. Pharm. 2016 Adv., 6, 811824, https://doi.org/10.5455/jppa.1969123104000. 